\title{
Metabolic and behavioral changes induced by chronic treatment with dexamethasone in mice: differential effects in males and females
}

\author{
Daniel Luiz de Medeiros ${ }^{\mathrm{a}}$, André Vinícius Martinhago a ${ }^{\text {a }}$ Eduardo Luiz Gasnhar \\ Moreira $^{\mathrm{a}, \mathrm{b}}$, Eslen Delanogare $\mathrm{b}^{\mathrm{w}^{*}}$ \\ a'Departamento de Ciências Fisiológicas, Neuroscience Coworking Lab, \\ Universidade Federal de Santa Catarina, Florianópolis, SC, Brasil \\ ${ }^{\text {b} P r o g r a m a ~ d e ~ P o ́ s-G r a d u a c ̧ a ̃ o ~ e m ~ N e u r o c i e ̂ n c i a s, ~ N e u r o s c i e n c e ~ C o w o r k i n g ~ L a b, ~}$ \\ Universidade Federal de Santa Catarina, Florianópolis, SC, Brasil
}

Histórico do Artigo:

Recebido em:

14/04/2020

Aceito em:

$16 / 05 / 2020$

Keywords:

Stress; depression; metabolism

\section{Palavras-chave:}

Estresse; depressão; metabolismo

\begin{abstract}
Stress is characterized as one of the main factors that contribute to the development of psychiatric and metabolic diseases. Through excessive activation of the hypothalamic-pituitary-adrenal (HPA) axis, and the resulting release of cortisol (in humans) or corticosterone (in rodents), the chronic increase in these hormones has been shown to contribute significantly to the development of depression and type 2 diabetes. Given the increase in mental disorders and metabolic pathologies in recent years, a better understanding of the factors contributing to the development of these conditions has become an important object of study. Here, we evaluated the behavioral and metabolic effects of chronic administration of dexamethasone, at a dose of $4 \mathrm{mg} / \mathrm{kg}$, for 21 days, in male and female mice. The results indicate that dexamethasone treatment resulted in anxious likebehavior and passive stress-coping behavior in male and female mice. Moreover, we uncover sexspecific outcomes of chronic dexamethasone treatment on metabolic phenotypes in mice. Treatment with dexamethasone specifically resulted in a significant weight loss and increased plasma concentration of total proteins in male mice. Also, dexamethasone-induces hypercholesterolemia was observed in both male and female mice, although it did not impact glucose levels and glucose tolerance after glucose loading. The present study reproduced some metabolic and behavioral effects observed in humans exposed to excess glucocorticoids, providing preclinical evidence for future studies.
\end{abstract}

Alterações metabólicas e comportamentais induzidas pelo tratamento crônico com dexametasona em camundongos: diferentes efeitos em machos e fêmeas

\section{RESUMO}

O estresse é caracterizado como um dos principais fatores que contribuem para o desenvolvimento de doenças psiquiátricas e metabólicas. Através da ativação excessiva do eixo hipotálamopituitária-adrenal (HPA) e a consequente liberação de cortisol (em humanos) ou corticosterona (em roedores), o aumento crônico desses hormônios demonstrou contribuir significativamente para o desenvolvimento de, por exemplo, depressão e diabetes tipo 2. Dado o aumento acentuado de transtornos mentais e patologias metabólicas nos últimos anos, uma melhor compreensão dos fatores que contribuem para o desenvolvimento dessas condições se tornou um importante objeto de estudo. Aqui, avaliamos os efeitos comportamentais e metabólicos da administração crônica de dexametasona, na dose de $4 \mathrm{mg} / \mathrm{kg}$ por 21 dias, em camundongos machos e fêmeas. Os resultados indicam que o tratamento com dexametasona resultou em comportamento ansioso e comportamento passivo de enfrentamento diante de um estresse agudo em camundongos machos e fêmeas. Além disso, o tratamento com dexametasona resultou em significativa perda de peso e aumento das concentrações plasmáticas de proteínas totais apenas em camundongos machos. Entretanto, o tratamento com dexametasona induziu hipercolesterolemia em camundongos machos e fêmeas. Todavia, não foi observado diferença na glicemia dos animais no GTT. Os resultados sugerem que, em termos comportamentais, camundongos machos e fêmeas respondem de maneira semelhante à dexametasona, embora tenham sido observadas respostas metabólicas diferentes entre os sexos. O presente estudo reproduziu parcialmente os efeitos metabólicos e comportamentais observados em humanos expostos ao excesso de glicocorticóides, fornecendo evidências pré-clínicas para futuros estudos.

\footnotetext{
* Corresponding author: eslenneuro@gmail.com (Delanogare E.)
} 


\section{Introduction}

The concept of stress was characterized by Selye, in 1936, as an orchestrated physiological response to harmful stimuli (e.g., electric shock, extreme cold, and surgical injury) (1). The stress response involves activating the hypothalamic-pituitary-adrenal axis (HPA). First, the hypothalamus synthesizes and releases the corticotrophin-releasing hormone $(\mathrm{CRH})$, which, in turn, acts on the pituitary gland stimulating the release of adrenocorticotrophic hormone $(\mathrm{ACTH})$, that, through the bloodstream, acts on the adrenal gland, releasing the hormone cortisol (corticosterone in rodents) (2). Physiologically, cortisol is involved in several processes, such as energy mobilization, water balance, immunosuppressive response, and cardiovascular function (3). Once in the bloodstream, cortisol will act as a negative feedback loop, inhibiting the release of CRH and ACTH (2).

Excessive activation of the HPA axis causes a marked increase in the release of glucocorticoids, leading to a condition known as hypercortisolemia, resulting in several changes in the body that can culminate in the development of diseases. For example, hypercortisolemia has been considered as a major contributor to the development of psychiatric diseases, such as depression and comorbidities $(4,5)$ and metabolic diseases, such as type 2 diabetes mellitus (6). Patients with Cushing's disease, characterized by a high concentration of plasma cortisol, present psychiatric disorders ( $70 \%$ of cases) and glucose intolerance ( $60 \%$ of cases) (7). In rodents, dysfunction of the HPA axis can be induced through acute or chronic administration of glucocorticoids, such as dexamethasone, which results in passive stress-coping behavior, increased anxiety-like behavior, and metabolic disorders, such as glucose intolerance (8-10).

The key role of HPA axis dysfunction, both in psychiatric and metabolic diseases, it is an important object of study. As an example, in 2017, it was estimated that $4.4 \%$ of the world population was affected by depression and $3.6 \%$ by anxiety disorder, both of which are more common in women (11). In fact, women are more likely to develop depression when compared to men, and this vulnerability may be linked to the different forms in which men and women respond to stressful events (12). Also, the number of people with disorders related to glucose metabolism, such as type 2 diabetes mellitus, increased from 108 million in 1980 to 422 million people in 2014 (13). It is worth mentioning that obesity, an important risk factor for the development of type 2 diabetes mellitus, is more prevalent in women (14). Considering that women are more susceptible to obesity, depression, and anxiety, here, we attempt to reproduce the metabolic and behavioral effects observed in humans exposed to excess glucocorticoids and analyze whether there is a difference in responses in male and female mice.

\section{Methods}

\subsection{Animals}

Experiments were carried out on 18 male and 18 female 2-month-old Swiss albino mice from the animal facility of Universidade Federal de Santa Catarina (UFSC, Florianópolis, Brazil), weighing around $40 \mathrm{~g}$ at the beginning of the experiments. They were kept in groups of 3 animals per cage (the experiment was performed in 3 different sets) in a room under controlled temperature $\left(23 \pm 1{ }^{\circ} \mathrm{C}\right)$ and subjected to a 12-h light cycle (lights on 7:00 a.m.) with free access to food and water. All procedures used complied with the guidelines on animal care of the local Ethics Committee on the Use of Animals (protocol 5497310718). 


\subsection{Experimental Design}

Mice were divided into four experimental groups: male treated with saline $(n=9)$, male treated with dexamethasone $(n=9)$, female treated with saline $(n=9)$, and female treated with dexamethasone $(n=9)$. The animals received, daily, for 21 days, saline solution $(\mathrm{NaCl} 0.9 \%)$ or dexamethasone $(4 \mathrm{mg} / \mathrm{kg}$ ), administered by the intraperitonel route (i.p.), according to the studies by Skupio and collaborators (10) and Delanogare and collaborators (29). After 17 days, still under the influence of the above-mentioned treatments, the animals were subjected to a battery of behavioral tests, consisting of elevated plus-maze test (day 17), tail suspension test (day 19), and open field test (day 20). One day after the last behavioral test, the animals, in a six-hour caloric fast, were submitted to the glucose tolerance test (day 21). One day later, the animals, under a sixhour caloric fast, were anesthetized with a mixture of ketamine $(80 \mathrm{mg} / \mathrm{kg}$; i.p. $)$ and xylazine $(10 \mathrm{mg} / \mathrm{kg}$; i.p.) and blood was collected by cardiac puncture to determine plasma cholesterol and total protein levels, as summarized in Figure 1.

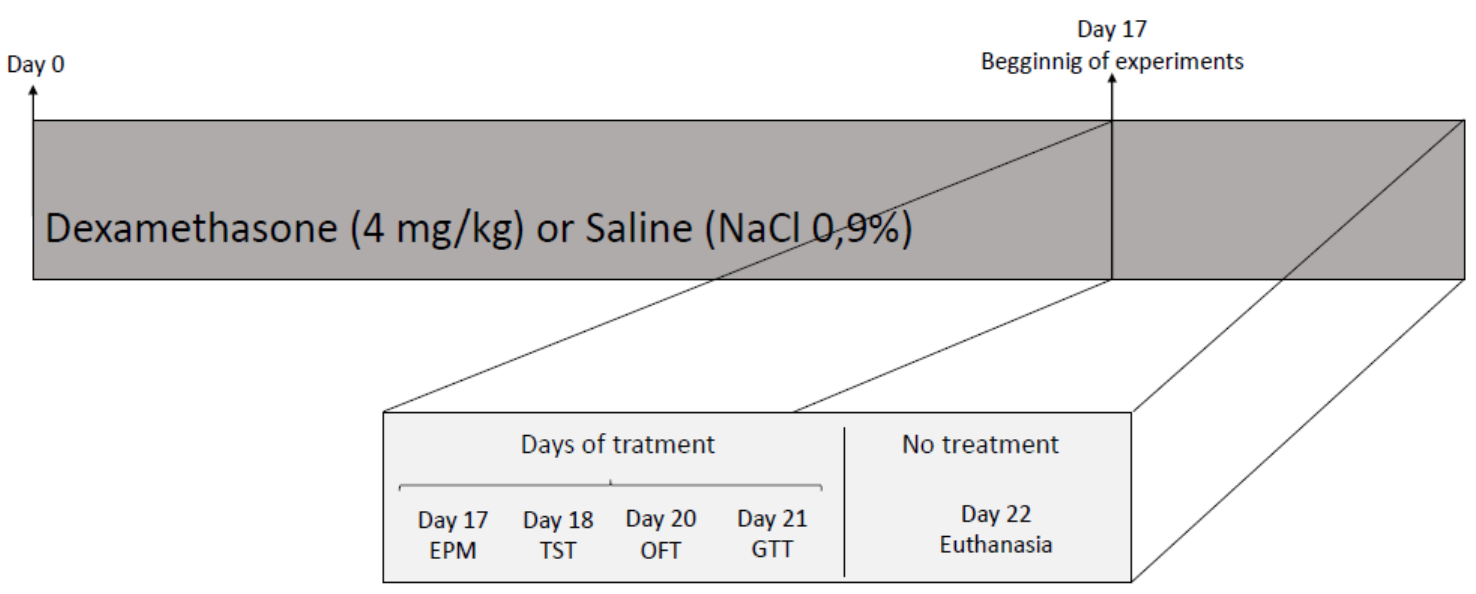

Figure 1 - Experimental design. Legend: EPM - Elevated plus maze; TST - Tail suspension test; OFT - Open field test and GTT - Glucose tolerance test.

\subsection{Behavioral Tests}

All experiments were conducted during the light phase (1:00-4:00 p.m.). Experiments were conducted in a controlled-temperature room $\left(23^{\circ} \mathrm{C}\right.$, the humidity was between $40 \%$ - 60\%), with low-light intensity (12 lx). Moreover, they were recorded (webcam Microsoft VX 3000) and the videos were analyzed manually by blind experimenters.

\subsubsection{Elevated Plus Maze Test (EPM)}

This test was first developed by Pellow and collaborators (15) in rats and, later, validated in mice by Lister (16). The EPM was used to evaluate the conflict between the innate fear of mice to open areas versus their desire to explore new environments, a well-established paradigm to assess anxiety-like behavior. The apparatus was made of wood covered with impermeable black Formica, elevated $60 \mathrm{~cm}$ above the floor, with four arms $(18 \mathrm{~cm}$ long, $6 \mathrm{~cm}$ wide) arranged in the shape of a plus sign. Two opposite arms were surrounded by walls ( $6 \mathrm{~cm}$ high, enclosed arms), while the other two were devoid of enclosing walls 
(open arms). The four arms were connected by a central platform $(6 \times 6 \mathrm{~cm})$. Each animal was individually placed in the central area of the maze facing an enclosed arm and observed for $5 \mathrm{~min}$. The number of entries (defined by the placement of the four paws into an arm), and the time spent in open and enclosed arms were recorded. The percentage of open arm entries and time were calculated by the number of open arm entries divided by the total number of arm entries. The number of enclosed arms entries was used as a measure of locomotor activity.

\subsubsection{Tail Suspension Test (TST)}

The TST evaluates coping strategy to acute inescapable stress (17). Developed by Steru et al. (18), based on the premise that an animal subjected to a stressful and inescapable situation exhibits two types of alternating behaviors, the agitation characteristic of the attempt to escape from the stressful situation, and immobility. It was observed that antidepressant drugs decrease the duration of immobility in this test (18). Mice both acoustically and visually isolated were suspended $30 \mathrm{~cm}$ above the floor by an adhesive tape placed approximately $1 \mathrm{~cm}$ from the tip of the tail. The animals did not have access to any wall or compartment that could favor the climb. The test was recorded, with the video camera, over $6 \mathrm{~min}$. The time to the first immobility (latency) and the total immobility time was observed. Immobility was characterized as the absence of anybody movement.

\subsubsection{Open Field Test (OFT)}

The natural tendency of the animal in a new environment is to exploit it, despite the stress and conflict caused by the new environment (19). This behavioral parameter allows the assessment of spontaneous rodent locomotor activity and has been used to analyze the putative effect of drugs on the central nervous system, with agents that suppress locomotor activity present sedative action/properties and agents that increase locomotor activity stimulating properties (20). In this test, the animals are allowed free exploration in an apparatus of $50 \mathrm{~cm} \times 50 \mathrm{~cm} \times 40 \mathrm{~cm}$ in size, divided by 12 peripheral quadrants and 4 central quadrants. The peripheral area consists of the quadrants close to the edges, while the central area consists of quadrants located in the center, away from the edges. The exploration time was 5 minutes per animal. The following behavioral parameters were evaluated: \% of crossings in the central area, the total number of crossings, and time spent in the central area of the apparatus.

\subsection{Biochemical Analysis}

Quantifications of total cholesterol and total proteins in plasma were performed using commercial reagents (Gold Analisa, Belo Horizonte, MG, Brazil), following the manufacturer's specifications. Glucose tolerance tests were performed through i.p. application of D - (+) - glucose (Sigma Aldrich, St Louis, MO) at a concentration of 2 $\mathrm{g} / \mathrm{kg}$ of body weight. Glucose concentration in peripheral blood was measured with a glucose meter (Accu-Chek Performa ${ }^{\circledR}$ ) before i.p. (basal) and at times 15, 30, 60, and 120 min after application. For the calculation of the area under the curve (AUC), the average value of each group at time 0 was used as a baseline. The results are expressed in $\mathrm{mg} / \mathrm{dl}$.

\subsection{Statistical analysis}


The results are presented as the mean + standard error of the mean (SEM). Statistical analyzes were performed using the two-way analysis of variance (ANOVA) with or without repeated measures. Following significant ANOVAs, the Newman Keuls test was used for multiple post hoc comparisons. $\mathrm{P}$ values less than $0.05(* \mathrm{P}<0.05)$ were considered as indicative of significance. All tests were performed using the STATISTICA® software package (StatSoft Inc, Tulsa, OK, USA) and all graphics were created by GraphPad Prism 6.

\section{Results}

\subsection{Elevated Plus Maze Test}

The two-way ANOVA indicated a significant main effect for sex on the $\%$ of open arms time $[\mathrm{F}(1,32)=4.98, \mathrm{p}<0.05]$ and on the $\%$ of time in the open arms $[\mathrm{F}(1,32)=5.58$, $\mathrm{p}<0.05$ ] (Figures $2 \mathrm{~A}$ and B, respectively). Subsequent post-hoc analysis indicated no differences between groups. On the other hand, the two-way indicated no significant effects on the number of enclosed arms entries (Figure 2C).

\section{ELEVATED PLUS MAZE}

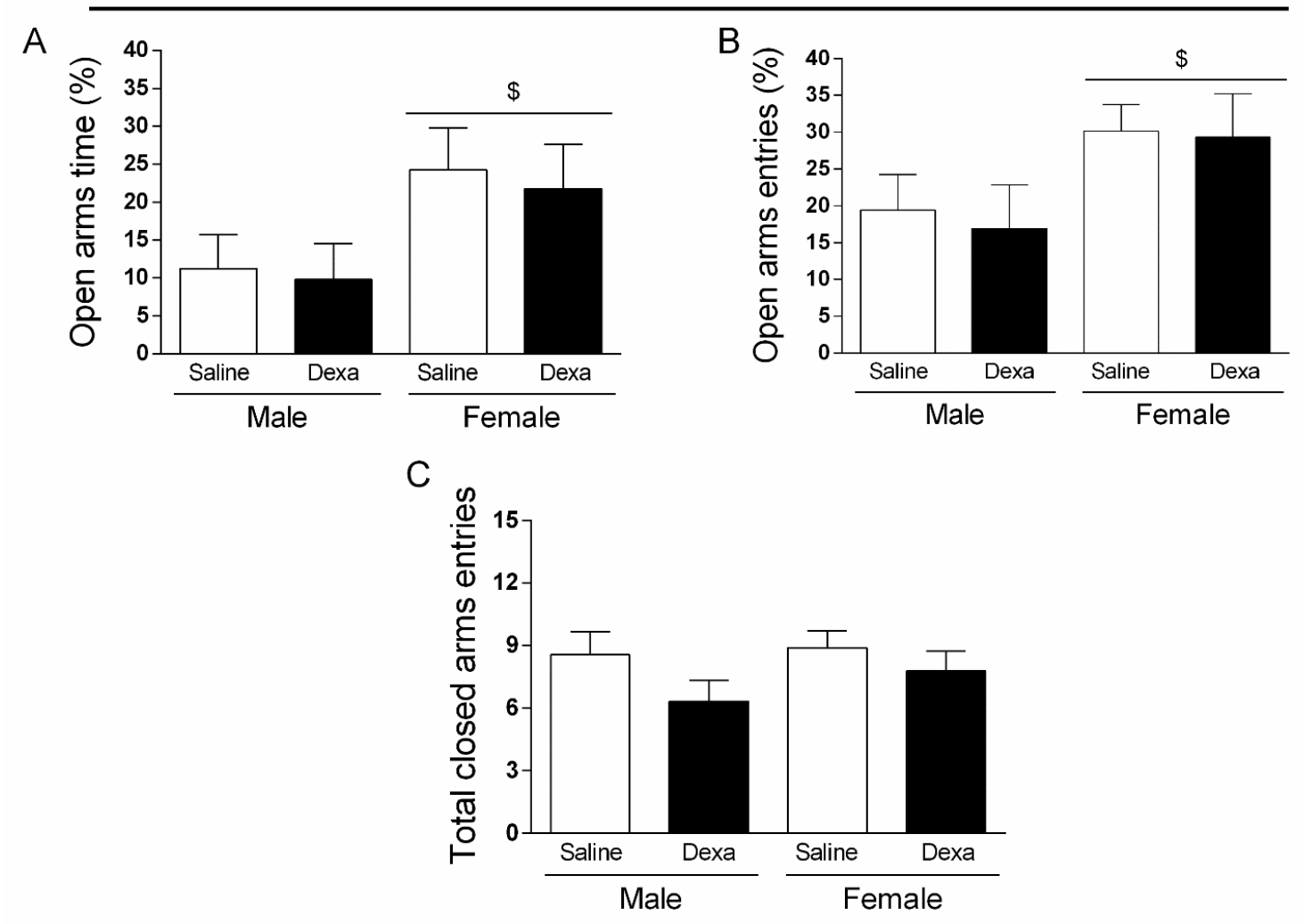

Figure 2 - Elevated Plus Maze (A-C). (A) Open arms time (\%). (B) Open arms entries (\%). (C) Total closed arms entries. The data are expressed as mean + standard error of the mean (SEM). $\$ \mathrm{p}<0.05$ for ANOVA sex factor (two-way ANOVA).

\subsection{Tail Suspension Test}

The two-way ANOVA indicated a significant main effect for sex $[\mathrm{F}(1,32)=7.28$, $\mathrm{p}<0.05]$ and for treatment $[\mathrm{F}(1,32)=4.75, \mathrm{p}<0.05]$ on the latency to immobility (Figure 
3A). Subsequent post hoc analysis revealed a significant decrease in the latency to immobility in males treated with dexamethasone $(\mathrm{p}<0.05)$ and females treated with saline ( $p<0.05)$ when compared with males treated with saline. Moreover, the two-way ANOVA indicated a significant main effect for treatment $[\mathrm{F}(1,32)=59.9, \mathrm{p}<0.05]$ on the immobility time (Fig. $3 \mathrm{~B}$ ). The post hoc analysis indicated a significant increase in the immobility time in both dexamethasone-treated groups when compared with their respective control group ( $\mathrm{p}<0.05)$.

\section{TAIL SUSPENSION TEST}
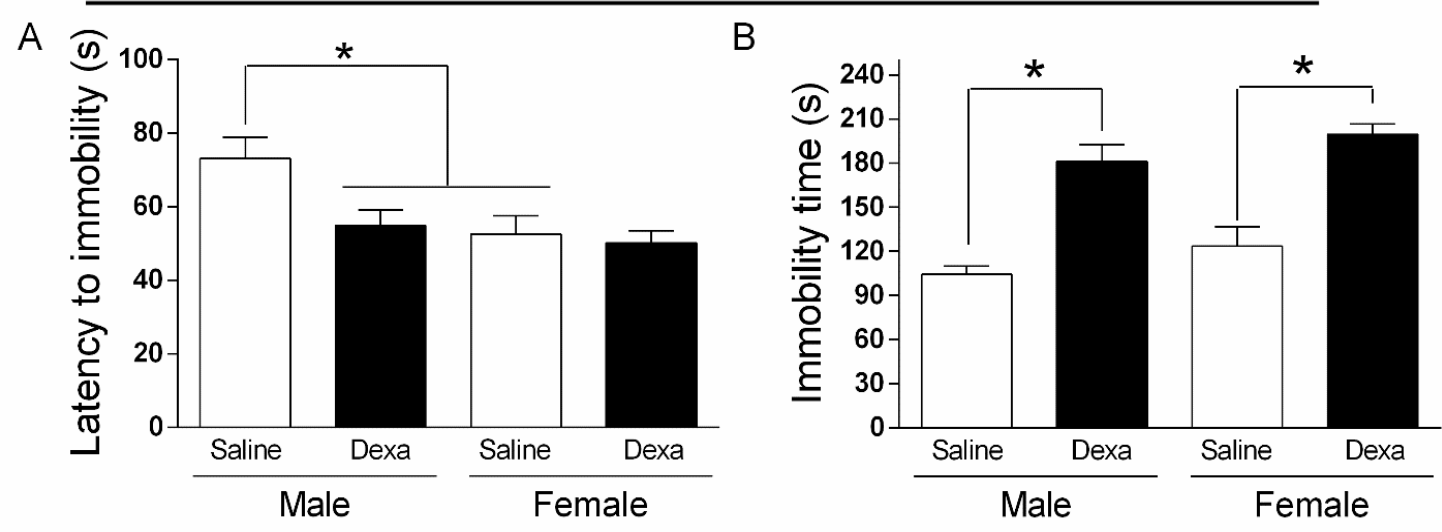

Figure 3 - Tail suspension test (A-B). (A) Latency for immobility (s). (B) Immobility time (s). Data are expressed as mean + standard error of the mean (SEM). $*$ p $<0.05$ difference between groups (two-way ANOVA followed by Newman - Keuls post hoc).

\subsection{Open Field Test}

The two-way ANOVA indicated a significant main effect for treatment $[\mathrm{F}(1,31)=7.48$, $\mathrm{p}<0.05$ ] on center time (Fig. 4 A). Subsequent post hoc analysis indicated no differences between groups. Additionally, the two-way ANOVA indicated a significant main effect for sex on the percentage of center crossings [(1, 31) $=13,15, \mathrm{p}<0.05]$ (Figure 4B). Subsequent post hoc analysis indicated a significant decrease in the percentage of center crossings in both female groups when compared with their respective male group ( $\mathrm{p}<$ 0.05). The two-way ANOVA indicated a significant main effect for sex on total crossings $[\mathrm{F}(1,31)=7.63, \mathrm{p}<0.05]$ (Figure 4C). Subsequent post hoc analysis indicated a significant increase in the number of total crossings in saline-treated female mice in comparison with saline-treated male mice $(\mathrm{p}<0.05)$ and with dexamethasone-treated female mice ( $p<0.05$ ). Of note, one of the animals of the dexamethasone-treated female mice did not explore the apparatus, being characterized as a significant outlier by the Grubbs' statistical test, thus being excluded from the statistical analyses. 
OPEN FIELD TEST

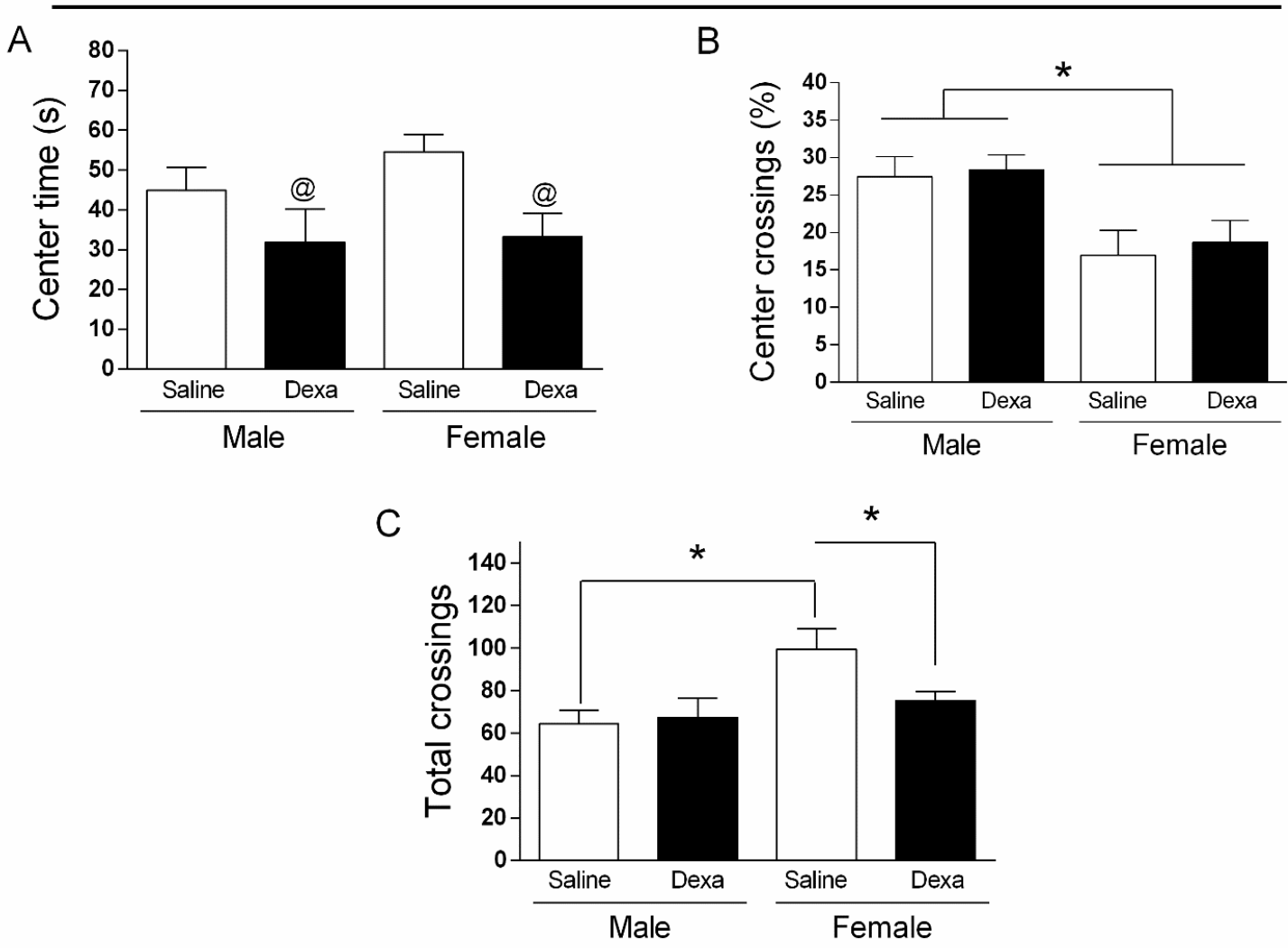

Figure 4 - Open field test (A-C). (A) Center time (s). (B) Center crossings (\%). (C) Total crossings. Data are expressed as mean + standard error of the mean (SEM). * p $<0.05$ difference between groups; $\$ \mathrm{p}<0.05$ for ANOVA sex factor and @ for ANOVA treatment factor (two-way ANOVA followed by Newman - Keuls post hoc).

\subsection{Biochemical Analysis}

The two-way ANOVA showed a significant main effect for treatment $[\mathrm{F}(1,32)=5.32$, $\mathrm{p}<0.05]$, for sex $[\mathrm{F}(1,32)=12.15, \mathrm{p}<0.05]$ and for treatment by sex interaction $[\mathrm{F}(1$, $32)=17.06, \mathrm{p}<0.05]$ on body mass variation (Figure 5A). Post hoc analysis revealed a significant loss of body mass $(\mathrm{g})$ in dexamethasone-treated male mice when compared with saline-treated male mice $(\mathrm{p}<0.05)$ and with dexamethasone-treated female mice $(\mathrm{p}$ $<0.05)$. 


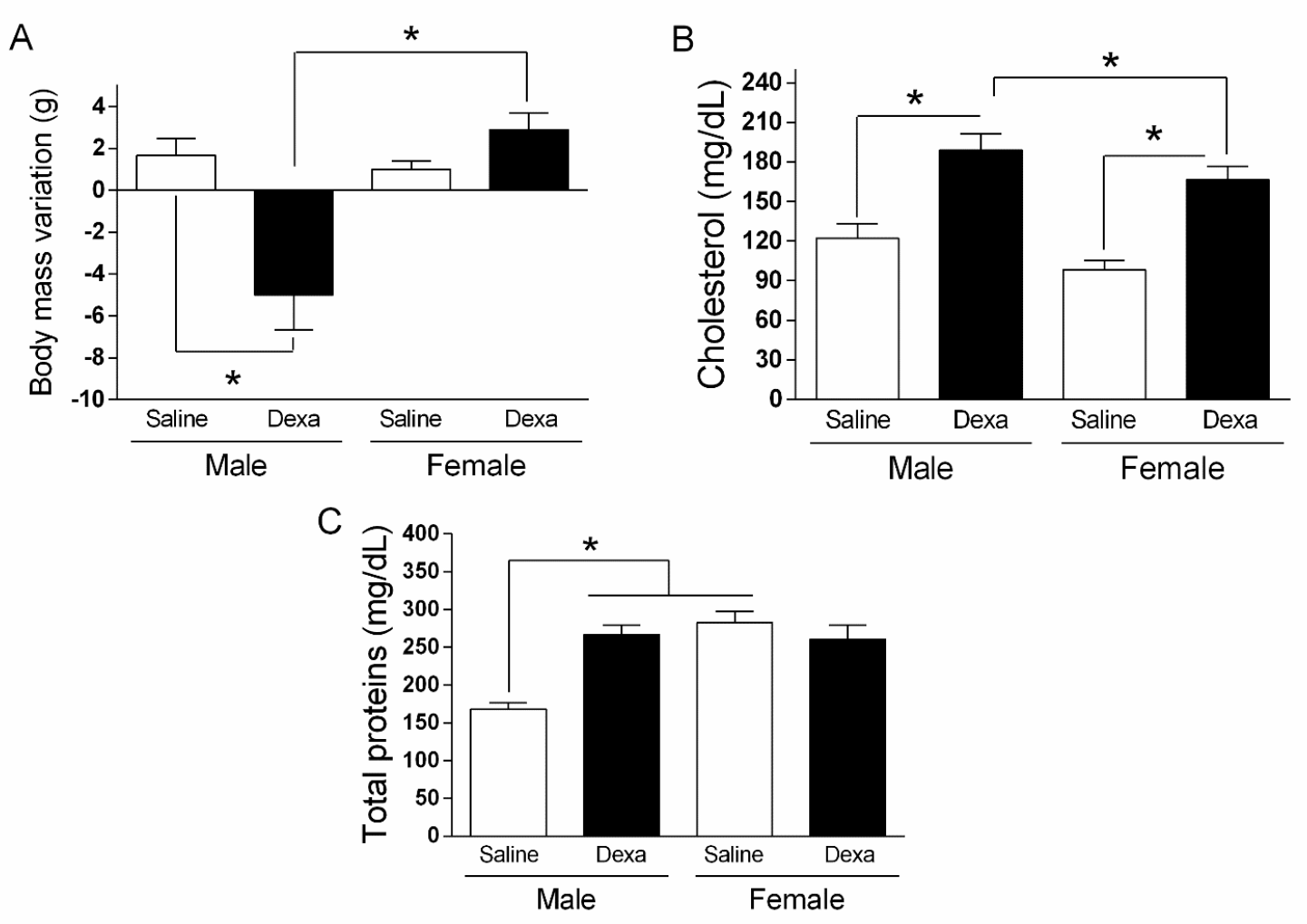

Figure 5 - Biochemical analysis (A-C). (A) Body mass variation (g). (B) Total cholesterol. (C) Total proteins. Data are expressed as mean + standard error of the mean (SEM). $* \mathrm{p}<0.05$ difference between groups (two-way ANOVA followed by Newman Keuls post hoc).

The two-way ANOVA indicated a significant main effect for $\operatorname{sex}[\mathrm{F}(1,32)=4.84, \mathrm{p}$ $<0.05]$ and for treatment $[\mathrm{F}(1,32)=41.78, \mathrm{p}<0.05]$ on plasma cholesterol levels. Subsequent post hoc analysis indicated a significant increase in the cholesterol levels of dexamethasone-treated mice in comparison with saline-treated mice, in both sex (p $<0.05)$. Also, the post hoc test indicated a significant decrease in the plasma cholesterol levels in dexamethasone-treated female mice when compared with dexamethasonetreated male mice $(\mathrm{p}<0.05)$ (Figure 5B).

The two-way ANOVA indicated a significant main effect for treatment $[\mathrm{F}(1,32)=7.27$, $\mathrm{p}<0.05]$, for $\operatorname{sex}[\mathrm{F}(1,32)=14.690, \mathrm{p}<0,05]$, and for treatment by sex interaction $[\mathrm{F}(1$, $32)=18.34, \mathrm{p}<0.05]$ on plasma protein levels. The post hoc analysis showed a significant increase in plasma protein levels in dexamethasone-treated male mice in comparion with saline-treated male mice ( $\mathrm{p}<0.05)$. Also, post hoc analysis indicated a significant increase in plasma protein levels in saline-treated female mice when compared to saline-treated male mice ( $\mathrm{p}<0.05$ ) (Figure 5C).

Concerning the glucose tolerance test, two-way ANOVA with repeated measures indicated a significant main effect for repetition $[\mathrm{F}(4,140)=88.78, \mathrm{p}<0.05]$ and for repetition by sex interaction $[\mathrm{F}(4,140)=4.35, \mathrm{p}<0.05]$ (Figure 6A). Subsequent posthoc comparisons indicated no significant differences between groups at each time point. Moreover, the two-way ANOVA indicated no significant effects on the area under the curve (Figure 5B). Concerning the basal glucose, the two-way ANOVA also did not indicate significant effects (Figure 6C). 
A

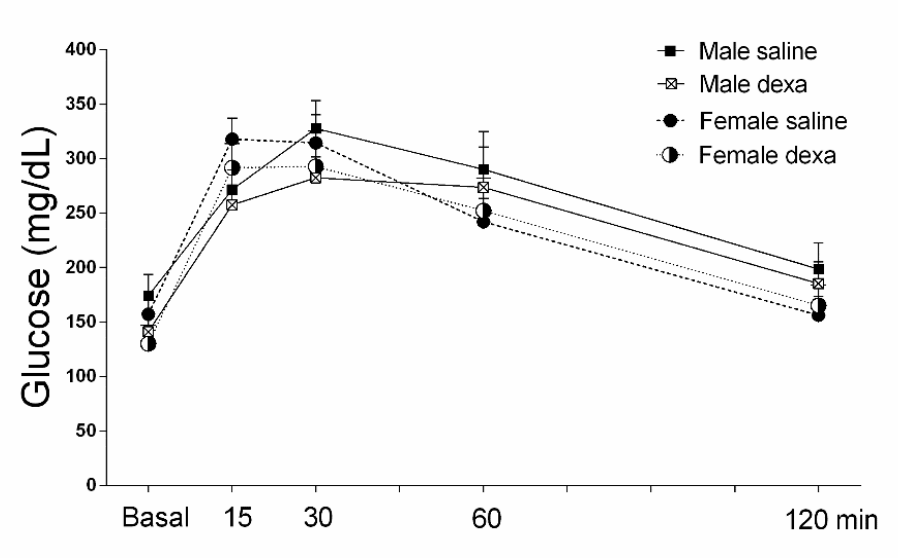

B

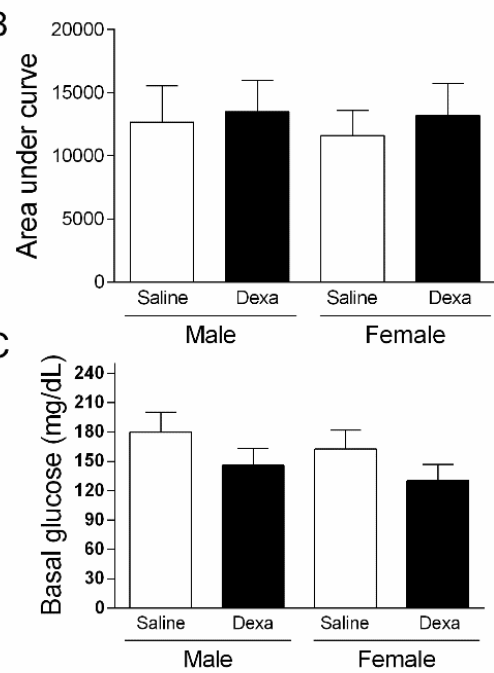

Figure 6 - Glucose tolerance test (A-B) and basal glucose (C). (A) Glucose curve, (B) Area under curve and $(\mathrm{C})$ basal glucose. Data are expressed as mean + standard error of the mean (SEM).

\section{Discussion}

The present study aimed at comparing the impact of sex on the dexamethasone-induces behavioral and metabolic impairments in mice. The administration protocol was based on a previous study by Skupio and colleagues (10). It is noteworthy that previous studies used only male mice $(10,29)$. Specifically, on the one hand, the present study demonstrated that chronic dexamethasone treatment induces passive stress-coping behavior, anxiety-like behavior, body weight loss, hypercholesterolemia, and hyperproteinemia in male mice, as in previous studies $(10,29)$. On the other hand, the present study demonstrated for the first time that the same treatment protocol is capable of inducing similar behavioral results in female mice, although female mice were less susceptible to dexamethasone-induces metabolic dysfunction.

The present study did not observe significant effects of dexamethasone in the animals' behavior on the EPM. Onaolapo et al. (21) showed that male mice treated with dexamethasone, at a dose of $1.5 \mathrm{mg} / \mathrm{kg}$ (o.g.), for 14 days, presented a decrease in the percentage of time spent in the open arms (21). On the other hand, Demuyser and collaborators (22) showed that $\mathrm{C} 57 \mathrm{~B} 1 / 6$ male mice treated with corticosterone, for 21 days, at a dose of $20 \mathrm{mg} / \mathrm{kg}$, presented no differences in the time spent in the open arms of the EPM (22). However, we observed a sex-specific behavioral phenotype, where saline-treated female mice had an increase in the percentage of time in the open arms and the percentage of entries in the open arms in comparison with saline-treated male mice. Several studies pointed out differences in coping patterns of male and female rodents in the face of an anxiogenic situation (23). For example, the open arms of the EPM it seems more explored by females than by males (24). The reason why females explored the apparatus more when compared to males is still uncertain. However, the literature suggests that an evolutionary framework may be an explanation for this. Females, as potential mothers, would have a greater tendency to explore the environments, to ensure a safe and peaceful course of pregnancy (25). For example, Tucker and collaborators (26) 
analyzed the behavioral differences between male and female mice in the EPM and, in fact, observed that females had more locomotor activity than males (26).

In our study, we observed that dexamethasone-treated female mice showed a decrease in the number of total crossings in the OFT when compared with saline-treated female mice. In this regard, Yilmaz and collaborators (28) demonstrated that dexamethasone decreased the total crossings of male rats in the OFT (28). On the other hand, Rosa and collaborators (27) demonstrated that corticosterone, at a dose of $20 \mathrm{mg} / \mathrm{kg}$, for 21 days, did not influence spontaneous locomotion of female mice in the OFT (27). Herein, we observed that treatment with dexamethasone decreased the time spent in the center of the apparatus in both sexes. In a previous study, we already observed such an effect on male mice (29). In females, however, the data in the literature are controversial and are influenced by variations in the phases of the estrous cycle (23). This is a limitation of our study, which did not control the estrous cycle. Both, EPM and OFT tests are based on the premise that open spaces are aversive to rodents and, therefore, the increased exploration of these locations would result in less anxious-type behavior, however, although starting from the same premise, there is a difference in the results of both tests (30).

Moreover, it was demonstrated here that dexamethasone treatment induced a passive stresscoping behavior, observed by the increased immobility in the TST, in both males and females. The increase in immobility time in the TST induced by natural and synthetic glucocorticoids is consistent both in females $(31,32)$ and in males $(33,34)$. Indeed, from a neurobiological point of view, stress and HPA-axis dysfunction result in, for example, dendritic atrophy (35), changes in serotonergic function (36), decreased neuroplasticity and brain-derived neurotrophic factor (BDNF) $(37,38)$, a factor found in lower concentrations in post-mortem analyses of patients with a history of depression (37).

Dexamethasone treatment also induced significant metabolic changes in mice, although sex-differences were observed. Glucocorticoids have known catabolic properties, e.g., increased degradation and decreased protein synthesis (39). Here, it was observed that males treated with dexamethasone showed a significant loss of body mass. However, this effect was not observed in females. These sex-specific differences might be attributed to hormonal differences. Dakin et al. (40) demonstrated that estrogen, a primarily female hormone, plays an important role in the face of metabolic insults. The authors demonstrated that male mice are more susceptible to metabolic dysregulations induced by an obesogenic diet. Additionally, the study showed that treating males with estrogen not only reversed the metabolic damage induced by diet but also resulted in a similar response to glucocorticoids in both sexes, suggesting a role of the sex hormones in the animals' metabolic responses (40).

Dexamethasone treatment specifically increased the plasma protein levels in males. This evidence may partially explain the sex-specific effects of dexamethasone on body mass variation: the increased levels of plasma proteins in males are consistent with the decreased body mass. Additionally, we observed that saline-treated female mice have higher plasma levels of total proteins when compared with saline-treated male mice. In this regard, previous studies suggest a distinct pattern of blood proteins in males and females $(41,42)$. In addition, it was observed that dexamethasone increased the plasma cholesterol levels in both sexes. Kumar and collaborators (43) demonstrated that the administration of dexamethasone in rats increases cholesterol. Nevertheless, therapies that involve the use of glucocorticoids commonly result in dyslipidemia, including increased plasma cholesterol concentrations (44), probably due to increased cholesterol secretion by the liver due to changes in the genes involved in cholesterol biosynthesis $(43,45)$. We observed that dexamethasone did not impact glucose tolerance after glucose loading. It is known that glucocorticoids have diabetogenic properties, however, the 
development of glucose-related metabolic disorders through the use of glucocorticoids seems to occur in a dose (46) and time-dependent manner (47). Here, we hypothesize that the diabetogenic effect of dexamethasone led to an increase in blood glucose, which was counterbalanced by the increase in insulin secretion by pancreatic beta cells, i.e. adaptive response from pancreatic beta cells. The measurement of plasma insulin concentrations would be important data to confirm this hypothesis. This is a limitation of this work, requiring further studies to better clarify them.

\section{Conclusion}

Together, the results of the present study shown that chronic dexamethasone treatment induces depressive- and anxiety-like behavior both in male and female mice. Moreover, we uncover sex-specific outcomes of chronic dexamethasone treatment on metabolic phenotypes in swiss mice. Although dexamethasone increased plasma cholesterol levels in male and female mice, it specifically increased total plasma protein levels and induced weight loss in male mice. This data can be used as a subsidy for the design of future studies that aim to investigate the effect of stress on the development of psychiatric and metabolic disease, aiming at the development of therapeutic and/or protective strategies.

\section{Acknowledgements}

Research supported by grants from the Brazilian funding agencies: CAPES and CNPq (Universal 424799/2019-9). We are grateful to Professor Dr. Alex Rafacho for the critical reading of the manuscript and the considerations for the final version.

\section{References}

1. Selye, H. A Syndrome produced by Diverse Nocuous Agents. Nature 1936; 138 (32).

2. Aguilera, G. The Hypothalamic-Pituitary-Adrenal Axis and Neuroendocrine Responses to Stress. Handbook of Neuroendocrinology 2012; 175-196

3. Timmermans S, Souffriau J, Libert C. A General Introduction to Glucocorticoid Biology. Frontiers in Immunology 2019; 10: 1545.

4. Belmaker RH, Agam G. Major Depressive Disorder. New England Journal of Medicine 2008; 358(1): 55-68.

5. Menke A. Is the HPA Axis as Target for Depression Outdated, or Is There a New Hope? Frontiers in Psychiatry 2019; 10: 101.

6. Steffensen C, Pereira AM, Dekkers OM, Jørgensen JOL. Diagnosis of endocrine disease: Prevalence of hypercortisolism in type 2 diabetes patients: a systematic review and meta-analysis. European Journal of Endocrinology 2016; 175(6): 247-253.

7. Newell-Price J, Bertagna X, Grossman AB, Nieman LK. Cushing's syndrome. The Lancet 2006; 367(9522): 1605-1617.

8. Krishnan V, Nestler EJ. Animal models of depression: molecular perspectives. 2011; 7: 121-47.

9. Pasieka A, Rafacho A. Impact of Glucocorticoid Excess on Glucose Tolerance: Clinical and Preclinical Evidence. Metabolites 2016; 6(3): 24.

10. Skupio U, Tertil M, Sikora M, Golda S, Wawrzczak-bargiela A, Przewlocki R. Behavioral and molecular alterations in mice resulting from chronic treatment with dexamethasone: relevance to depression. Neuroscience 2015; 286(12):141-150

11. WHO. Depression and Other Common Mental Disorders. 2017 [Acessado em: 03/03/2020]. Disponível em: https://apps.who.int/iris/bitstream/handle/10665/254610/WHO-MSD-MER-2017.2eng.pdf 
12. Nolen-Hoeksema S. Gender Differences in Depression. Current Directions in Psychological Science 2001; 10(5): 173-176.

13. WHO. Diabetes Mellitus - epidemiology. 2. Diabetes Mellitus - prevention and control. 3. Diabetes, Gestational. 4. Chronic Disease. 5. Public Health. I. 2016 [Acessado em 03/03/2020. Disponível em: https://apps.who.int/iris/bitstream/handle/10665/204871/9789241565257_eng.pdf?sequence $=1$

14. Kautzky-Willer A, Harreiter J, Pacini G. Sex and Gender Differences in Risk, Pathophysiology and Complications of Type 2 Diabetes Mellitus. Endocrine Reviews 2016; 37(3): 278-316.

15. Pellow S, Chopin P, File SE, Briley M. Validation of open : closed arm entries in an elevated plusmaze as a measure of anxiety in the rat. Journal of Neuroscience Methods 1985; 14(3): 149-167.

16. Lister RG. The use of a plus-maze to measure anxiety in the mouse. Psychopharmacology 1987; 92 : 180-185.

17. Commons KG, Cholanians AB, Babb JA, Ehlinger DG. The Rodent Forced Swim Test Measures StressCoping Strategy, Not Depression-like Behavior. ACS Chemical Neuroscience 2017; 8(5): 955-960.

18. Steru L, Chermat R, Thierry B et al. The tail suspension test: A new method for screening antidepressants in mice. Psychopharmacology 1985; 85: 367-370.

19. Prut L, Belzung C. The open field as a paradigm to measure the effects of drugs on anxiety-like behaviors: a review. European Journal of Pharmacology 2003; 463(1-3): 3-33.

20. Archer J. Tests for emotionality in rats and mice: A review. Anim. Behav 1983; 21: 205-235.

21. Onaolapo OJ, et al. Dexamethasone Regimens Alter Spatial Memory and Anxiety Levels in Mice. Journal of Behavioral and Brain Science 2014; 4: 159-167.

22. Demuyser T, Bentea E, Deneyer L, Albertini G, Massie A, Smolders I. Disruption of the HPA-axis through corticosterone-release pellets induces robust depressive-like behavior and reduced BDNF levels in mice. Neuroscience Letters 2016; 626: 119-125.

23. Ter Horst, J. P., de Kloet, E. R., Schächinger, H., \& Oitzl, M. S. (2012). Relevance of stress and female sex hormones for emotion and cognition. Cellular and molecular neurobiology, 32(5), 725735 .

24. Leret ML, Molina-Holgado F, González MI. The effect of perinatal exposure to estrogens on the sexually dimorphic response to novelty. Physiology \& Behavior 1994; 55(2): 371-373.

25. Dubovicky M, Skultetyova I, Jezova D. Neonatal stress alters habituation of exploratory behavior in adult male but not female rats. Pharmacol Biochem Behav 1999; 64: 681-686

26. Tucker LB, McCabe JT. Behavior of Male and Female C57BL/6J Mice Is More Consistent with Repeated Trials in the Elevated Zero Maze than in the Elevated Plus Maze. Frontiers in Behavioral Neuroscience 2017; 11.

27. Rosa PB, Ribeiro CM, Bettio LE, Colla A, Lieberknecht V, Moretti M, Rodrigues AL. Folic acid prevents depressive-like behavior induced by chronic corticosterone treatment in mice. Pharmacol Biochem Behav 2014; 127:1-6.

28. Yılmaz T, Gedikli Ö, Yildirim M. Evaluation of spatial memory and locomotor activity during hypercortisolism induced by the administration of dexamethasone in adult male rats. Brain Research 2015; 1595:43-50.

29. Delanogare E, Souza RM, Rosa GK, Guanabara FG, Rafacho A, Moreira ELG. Enriched environment ameliorates dexamethasone effects on emotional reactivity and metabolic parameters in mice. Stress 2020.

30. Carola V, D’Olimpio F, Brunamonti E, Mangia F, Renzi P. Evaluation of the elevated plus-maze and open-field tests for the assessment of anxiety-related behaviour in inbred mice. Behavioural Brain Research 2002; 134(1-2): 49-57.

31. Freitas AE, Egea J, Buendia I, Gómez-Rangel V, Parada E, Navarro E, Casas AI, Wojnicz A, Ortiz JA, Cuadrado A, Ruiz-Nuño A, Rodrigues ALS, Lopez MG. Agmatine, by Improving Neuroplasticity Markers and Inducing Nrf2, Prevents Corticosterone-Induced Depressive-Like Behavior in Mice. Mol Neurobiol 2016; 53(5): 3030-3045.

32. Pazini FL, Cunha MP, Azevedo D, Rosa JM, Colla A, de Oliveira J, Rodrigues ALS. Creatine Prevents Corticosterone-Induced Reduction in Hippocampal Proliferation and Differentiation: Possible Implication for Its Antidepressant Effect. Molecular Neurobiology 2016; 54(8): 6245-6260.

33. Zhao YMAR, Shen J, Su H, Xing D, Du L. A mouse model of depression induced by repeated 
corticosterone injections. Eur J Pharmacol. 2008; 581(26): 113-20.

34. Ali SH, Madhana RM, KV, A, Kasala ER, Bodduluru LN, Pitta S, Lahkar M. Resveratrol ameliorates depressive-like behavior in repeated corticosterone-induced depression in mice. Steroids 2015; 101 : 37-42.

35. Chen, Y., Dubé, C. M., Rice, C. J., \& Baram, T. Z. Rapid loss of dendritic spines after stress involves derangement of spine dynamics by corticotropin-releasing hormone. The Journal of neuroscience: the official journal of the Society for Neuroscience 2008; 28(11): 2903-2911.

36. Lanfumey L, Mongeau R, Cohen-Salmon C, Hamon M. Corticosteroid-serotonin interactions in the neurobiological mechanisms of stress-related disorders. Neuroscience \& Biobehavioral Reviews 2008; 32(6): 1174-1184.

37. Duman RS, Monteggia LM. A Neurotrophic Model for Stress-Related Mood Disorders. Biological Psychiatry 2006; 59(12): 1116-1127.

38. Krishnan V, Nestler EJ. The molecular neurobiology of depression. Nature 2008; 455(7215): 894-902.

39. Klein GL. The effect of glucocorticoids on bone and muscle. Osteoporosis and Sarcopenia 2015; 1(1): 39-45.

40. Dakin RS, Walker BR, Seckl JR, Hadoke PW, Drake AJ. Estrogens protect male mice from obesity complications and influence glucocorticoid metabolism. International journal of obesity 2015; 39(10): 1539-1547.

41. Gersten DM, Khirabadi BS, Kurian P, Ledley RS, Mahany T, Ramey ER, Ramwell PW. Albumin obscures sex differences in blood protein patterns of rats and humans. The Biochemical journal 1980; 191(3): 869-872.

42. Tsuchiya N, Harada Y, Taki M, Minematsu S, Maemura S, Amagaya S. Age-related Changes and Sex Differences on the Serum Chemistry Values in Sprague-Dawley Rats. Experimental Animals 1994; 43(5): 671-678.

43. Kumar VS, Inamdar MN, Nayeemunnisa, Viswanatha G. Protective effect of lemongrass oil against dexamethasone induced hyperlipidemia in rats: possible role of decreased lecithin cholesterol acetyl transferase activity. Asian Pacific Journal of Tropical Medicine 2011; 4(8): 658-660.

44. Yadav A, Jahan A, Yadav TP, Sachdev N, Chitkara A, Asare R. Effect of Glucocorticoids on Serum Lipid Profile and Endothelial Function and Arterial Wall Mechanics. The Indian Journal of Pediatrics 2013; 80(12): 1007-1014.

45. Lemke U, Krones-Herzig A, Diaz MB, Narvekar P, Ziegler A, Vegiopoulos A, Herzig S. The Glucocorticoid Receptor Controls Hepatic Dyslipidemia through Hes1. Cell Metabolism 2008; 8(3): 212-223.

46. Rafacho A, Giozzet VA, Boschero AC \& Bosqueiro JR. Functional alterations in endocrine pancreas of rats with different degrees of dexamethasone-induced insulin resistance. Pancreas 2008; 36: 284-293

47. Rafacho A, Abrantes JL, Ribeiro DL, Paula FM, Pinto ME, Boschero AC, Bosqueiro JR. Morphofunctional alterations in endocrine pancreas of short- and long-term dexamethasone-treated rats. Horm Metab Res 2011; 43(4): 275-81. 